\section{D) Check for updates}

Cite this: Dalton Trans., 2020, 49 11736

Received 14th June 2020,

Accepted 7th August 2020

DOI: $10.1039 / \mathrm{dOdt02113j}$

rsc.li/dalton

\title{
Heterobimetallic propargyl gold complexes with $\pi$-bound copper or silver with enhanced anticancer activity $\dagger$
}

\begin{abstract}
Alice Johnson, (D) ${ }^{a}$ Isabel Marzo ${ }^{b}$ and M. Concepción Gimeno (D) *a
Several propargyl functionalised substrates with different heteroatoms ( $\mathrm{N}, \mathrm{O}$ or $\mathrm{S}$ ) have been used for the preparation of propargyl gold(I) phosphine complexes. The complexes were prepared in high yields either by reaction of the substrate with $\left[\mathrm{Au}(\mathrm{acac}) \mathrm{PPh}_{3}\right]$ or by reaction of $\left[\mathrm{AuCl}\left(\mathrm{PPh}_{3}\right)\right]$ with potassium hydroxide and the substrate in methanol. Several of the complexes have been characterised by X-ray diffraction showing the presence of secondary bonds such as $\pi$-stacking and aurophilic interactions. The reaction of the propargyl gold(I) phosphine complexes with $\left[\mathrm{Cu}\left(\mathrm{NO}_{3}\right)\left(\mathrm{PPh}_{3}\right)_{2}\right]$ or $\left[\mathrm{Ag}(\mathrm{OTf})\left(\mathrm{PPh}_{3}\right)_{2}\right]$ afforded heterobimetallic complexes with $\pi$-coordination of $\left\{\mathrm{Cu}\left(\mathrm{PPh}_{3}\right)_{2}\right\}$ or $\left\{\mathrm{Ag}\left(\mathrm{PPh}_{3}\right)_{2}\right\}$ to the alkyne bond. When the substituent of the propargyl unit contained more strongly coordinating pyridine moieties, $\left[\left(\mathrm{PyCH}_{2}\right)_{2} \mathrm{NCH}_{2} \mathrm{C} \equiv \mathrm{CAuPPh}_{3}\right]$, coordination of the heterometal to the pyridine units occurred, displacing the phosphine groups and giving rise to a dimeric structure. The antiproliferative activity of the complexes against cisplatin resistant lung cancer cell line A549 was determined by MTT assay. The mononuclear gold complexes showed excellent activities with $I_{50}$ values $<14 \mu \mathrm{M}$. Coordination of copper of silver to the alkynyl fragment resulted in a significant increase in activity suggesting a synergistic effect between the two metal centres
\end{abstract}

\section{Introduction}

Following the serendipitous discovery of the anticancer activity of cisplatin over 50 years ago ${ }^{1}$ and its subsequent approval by the FDA for the treatment of cancers in 1978, there has been increasing interest in the use of transition metal complexes in cancer treatments. Despite the success of the platinum complexes, there are several known side-effects and increasing reports of cisplatin resistant cancers and hence considerable research is now focussed on other metals. Interest in gold(I) complexes initially arose as a result of the anti-rheumatic drug Auranofin (Fig. 1(a)) which has shown potent anticancer activity. ${ }^{2}$ Gold(I) has not only been shown to be better tolerated in vivo than platinum, but the mechanism of action is significantly different since gold(I) targets cellular enzymes rather than DNA. ${ }^{3,4}$ Of the gold(I) complexes reported to have anti-

\footnotetext{
${ }^{a}$ Departamento de Química Inorgánica, Instituto de Síntesis Química y Catálisis Homogénea (ISQCH), CSIC-Universidad de Zaragoza, 50009 Zaragoza, Spain. E-mail: gimeno@unizar.es

${ }^{b}$ Departamento de Bioquimica y Biología Celular, Universidad de Zaragoza-CSIC, 50009 Zaragoza, Spain

$\dagger$ Electronic supplementary information (ESI) available. CCDC 2009440-2009446. For ESI and crystallographic data in CIF or other electronic format see DOI: 10.1039/dodt02113j
}

cancer activity, alkynyl-gold(I)-phosphine complexes are among the most potent. ${ }^{5-14}$

The incorporation of a second different metal centre into a complex can alter the physiochemical properties significantly. This can be advantageous in the development of chemothera-

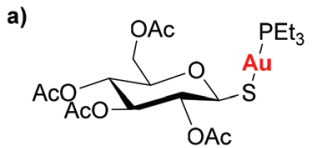

Auranofin

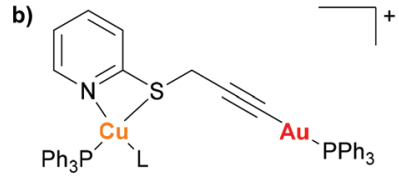

$L=P T A$, DAPTA
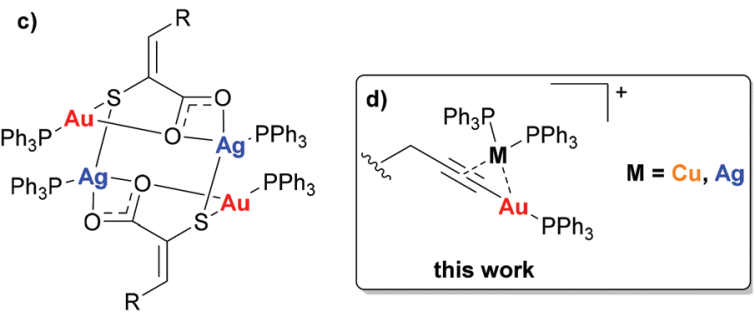

Fig. 1 (a) Auranofin, (b) $\mathrm{Au}(1)-\mathrm{Cu}(\mathrm{l})$ complexes reported by Laguna [PTA $=$ 1,3,5-Triaza-7-phosphaadamantane, DAPTA $=$ 3,7-diacetyl-1,3,7triaza-5-phosphabicyclo[3.3.1]nonane], ${ }^{16}$ (c) $\mathrm{Au}(\mathrm{I})-\mathrm{Ag}(\mathrm{I})$ complexes reported by Couce [R = phenyl, 2-chlorophenyl, 3-methoxyphenyl, 3-hydroxyphenyl, 2-furyl, 2-thienyl] ${ }_{1}^{17}$ (d) this work. 
peutic agents as a means of enhancing cytotoxicity. In these bimetallic compounds, where both metals could be cytotoxic via different mechanisms of action, there is the possibility for a synergistic effect due to the interaction with multiple biological targets, modulation in redox properties and/or changes in compound stability that could result in the improvement of the antitumor activity in comparison with the mononuclear precursors. ${ }^{15}$

There have been several reports of heterometallic complexes exhibiting such a synergistic effect between the metal centres, and the presence of two metal centres which display cytotoxic activity through different mechanisms of action can also prevent resistance occurring. However, there have been very few reported studies of the anticancer activity of heterometallic complexes of the coinage metals. Laguna and co-workers reported the anticancer activity of four $\mathrm{Au}(\mathrm{I})-\mathrm{Cu}(\mathrm{I})$ complexes (Fig. 1(b)) which all had $\mathrm{IC}_{50}$ values in the nanomolar range, significantly lower than cisplatin or Auranofin when tested under the same conditions. Although the mechanism of action of the heterometallic complexes was not fully understood the authors suggested that the complexes achieved the correct balance of hydrophilicity and lipophilicity to maximise the cytotoxicity. ${ }^{16}$ The only reported cytotoxic Au(I)-Ag(I) heterometallic complexes to date are a series of 3-(aryl)-2-sulfanylpropenoic acid derivatives reported by Couce and co-workers (Fig. 1(c)). The complexes exhibited greater cytotoxicity in the cervical cancer cell line A2780cisR, however no mechanistic studies were carried out. ${ }^{17}$ In general, the studies carried out with bimetallic complexes highlight that anti-proliferative properties are mainly driven by the most cytotoxic metal. However, the cooperative effect and synergism may be observed in metal-specific interactions with distinct biological targets or by improvement of the physicochemical properties of the final compounds. ${ }^{18}$

The $\pi$-coordination of a $\mathrm{Cu}\left(\mathrm{PPh}_{3}\right)_{2}$ or $\mathrm{Ag}\left(\mathrm{PPh}_{3}\right)_{2}$ group to an alkynyl-gold complex has previously been explored as a means of enhancing the luminescence. ${ }^{19,20}$ Such complexes can readily be synthesised and are known to be highly stable, however despite this their potential biological application has not been explored. Here were report the synthesis of a series of propargyl-Au(I)- $\mathrm{PPh}_{3}$ complexes and study their anticancer activity in a cisplatin resistant cancer cell line, A549. We then show how the alkyne bond can provide a coordination site for a second metal centre ( $\mathrm{Cu}$ or $\mathrm{Ag}$ ) giving complexes with improved cytotoxicity.

\section{Results and discussion}

\section{Synthesis and characterisation}

Propargyl functionalised substrates with different heteroatoms were chosen for the preparation of propargyl gold(I) phosphine complexes.

Propargyl gold(I) triphenylphosphine complexes 1-8 could be prepared by two different methods (Scheme 1). Addition of $\left[\mathrm{Au}(\mathrm{acac})\left(\mathrm{PPh}_{3}\right)\right]$ to a solution of the propargyl substrate in dichloromethane led to the formation of the complexes which could be isolated by concentration of the reaction solution and precipitation with diethyl ether, and were obtained in good yields (48-99\%). $\uparrow$ Alternatively, the products could be prepared by the addition of $\left[\mathrm{AuCl}\left(\mathrm{PPh}_{3}\right)\right]$ and potassium hydroxide to a solution of the substrate in methanol. This method avoids the need to prepare the acac gold(I) precursor and the products are obtained with high purity since they precipitate from the reaction solution, however, in most cases the yields were lower (12-91\%). All of the complexes were isolated as air-stable white solids. Successful reaction could be confirmed by the disappearance of the propargyl $\mathrm{CH}$ signal in the ${ }^{1} \mathrm{H}$ NMR spectra, and the ${ }^{31} \mathrm{P}$ NMR spectra all showed a sharp signal at around $42 \mathrm{ppm}$, a typical value for a triphenylphosphine group bound to gold(I) trans to a carbon-based ligand.

Complex 1 was found to be unstable in solution in dichloromethane, slowly converting into another product as observed

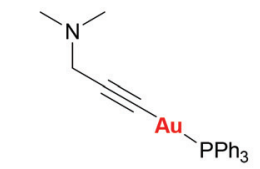

1

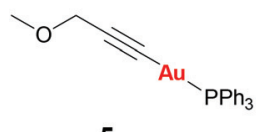

5
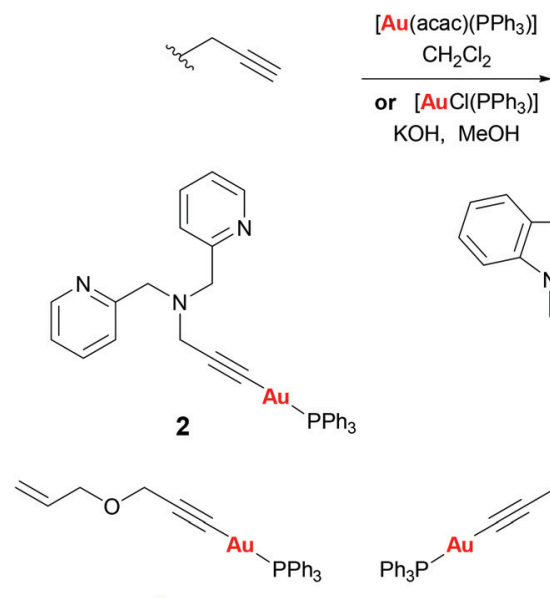

6

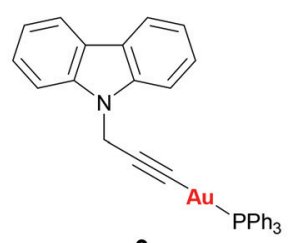

3

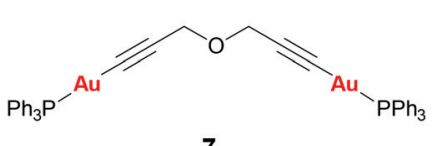

7
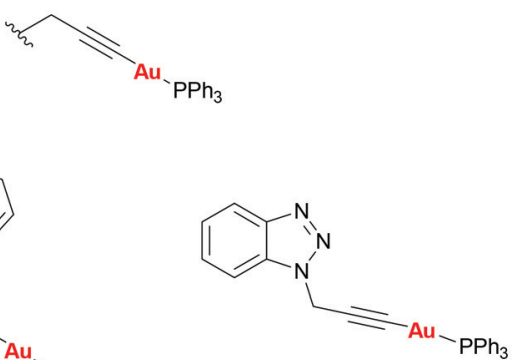

4

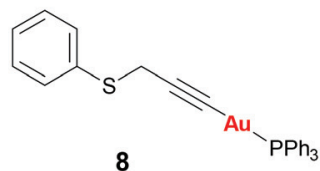

Scheme 1 Synthesis of complexes 1-8. 
by NMR studies (see ESI†). This is likely to be a dimeric or oligomeric species as a result of coordination of the sterically unhindered amine group to the gold centre. Complexes 2-8 were all stable in solution for at least $24 \mathrm{~h}$.

The nitrogen based propargyl derivatives 2-4 were characterised by single crystal X-ray diffraction (Fig. 2). In all cases the propargyl bond distances are typical of those expected for triple and single $\mathrm{C}-\mathrm{C}$ bonds. An almost linear geometry is observed about the gold centres and the trans influence of the phosphine ligand results in relatively long $\mathrm{Au}-\mathrm{C}$ bonds. The $\mathrm{Au}-\mathrm{C}$ distances are $\mathrm{Au}(1)-\mathrm{C}(1) 2.024(5) \AA$ for 2 , $\mathrm{Au}(1)-\mathrm{C}(1)$ 2.0004(18) Å for 3, and Au(1)-C(1) 1.997(3) Å for 4.

Complexes $\mathbf{3}$ and $\mathbf{4}$ have a structure in which the molecules are arranged in dimers as a result of $\pi$-stacking interactions. For complex 3 the six-membered ring of the carbazole unit of one molecule lies over the five-membered ring of the carbazole unit of another molecule with intermolecular distances centroid-centroid 3.551 ̊̊ and C(7)-N(1)' $3.546 \AA$ observed (Fig. 3). For complex 4 a slipped $\pi$-stacking interaction between the benzotriazole rings with a distance of $3.654 \AA$ is also observed (see $\mathrm{ESI} \dagger$ ).

The structure of the propargyl ether and thioether gold complexes 5 and $\mathbf{8}$ is shown in Fig. 4. The general bond lengths and angles are similar to those found in the complexes above. The Au-C distances are 2.005(5) for 5, 2.060(9) for 7 (Fig. 4) or 1.994(3) A for 8.

The dinuclear complex 7 is the only compound to display intermolecular aurophilic interactions in the solid state. This

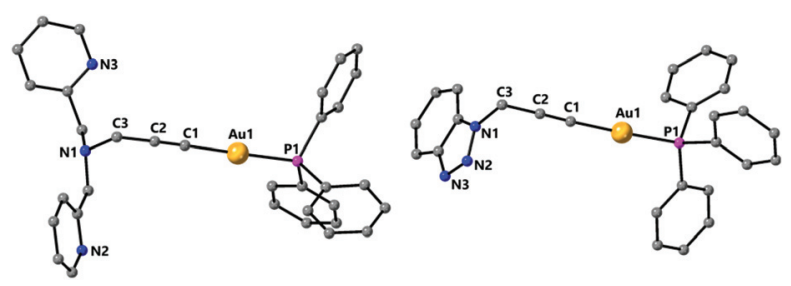

Fig. 2 Molecular structures of complexes 2 and 4 determined by single crystal X-ray diffraction. Selected bond lengths $[A ̊]$ and angles $\left[^{\circ}\right] 2$ : $A u(1)-C(1)$ 2.024(5), $A u(1)-P(1)$ 2.2711(13), C(1)-C(2) 1.173(7), C(2)-C(3) 1.487(8), $C(1)-A u(1)-P(1)$ 178.95(15), $C(1)-C(2)-C(3)$ 176.6(6); 4: $A u(1)-$ $C$ (1) 1.997(3), Au(1)-P(1) 2.2772(8), C(1)-C(2) 1.198(4), C(2)-C(3) 1.468(4), $C(1)-A u(1)-P(1) 175.31(8), C(1)-C(2)-C(3) 178.7(3)$.

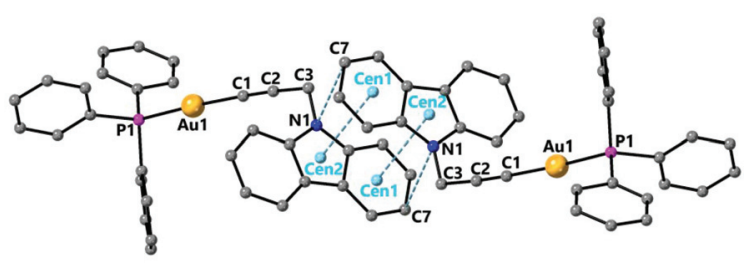

Fig. 3 Molecular structures of complex 3 determined by single crystal $\mathrm{X}$-ray diffraction showing $\pi$-stacking interactions. Selected bond lengths [Å] and angles [ $\left.{ }^{\circ}\right]$ : $\mathrm{Au}(1)-\mathrm{C}(1) 2.0004(18), \mathrm{Au}(1)-\mathrm{P}(1) 2.2686(8), \mathrm{C}(1)-\mathrm{C}(2)$ $1.200(2), C(2)-C(3)$ 1.472(2), $C(1)-A u(1)-P(1) 175.56(5), C(1)-C(2)-C(3)$ 173.60(17), Centroid(1)-Centroid(2) 3.551, C(7)-N(1)' 3.546.

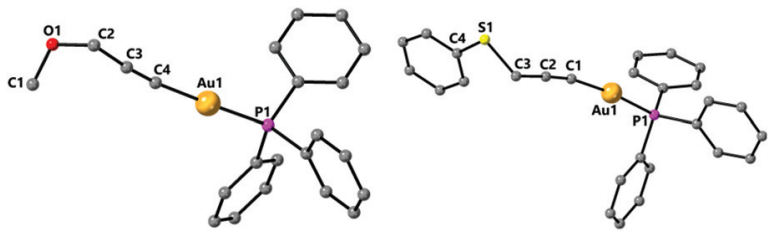

Fig. 4 Molecular structures of complexes 5 and 8 determined by single crystal X-ray diffraction. Selected bond lengths [Å] and angles [ $\left.{ }^{\circ}\right]$ 5: $\mathrm{Au}(1)-\mathrm{C}(4)$ 2.005(5), $\mathrm{Au}(1)-\mathrm{P}(1) 2.2870(12), \mathrm{O}(1)-\mathrm{C}(1) 1.393(7), \mathrm{O}(1)-\mathrm{C}(2)$ 1.416(6), $\quad C(2)-C(3) \quad 1.489(7), \quad C(3)-C(4) \quad 1.205(7), \quad C(4)-A u(1)-P(1)$ 178.38(15), $C(4)-C(3)-C(2)$ 174.4(5); 8: $A u(1)-C(1)$ 1.994(3), $A u(1)-P(1)$ $2.2766(7), S(1)-C(4) 1.763(3), S(1)-C(3) 1.818(4), C(1)-C(2) 1.206(4), C(2)-$ $C(3) 1.467(4), C(1)-A u(1)-P(1) 173.51(9), C(1)-C(2)-C(3) 175.1(3)$.

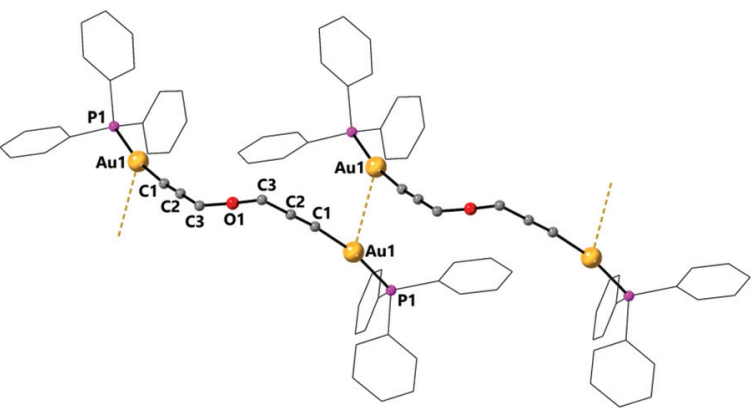

Fig. 5 Molecular structure of complex 7 determined by single crystal $X$-ray diffraction showing intermolecular aurophilic interactions. Selected bond lengths [Å] and angles [ $\left.{ }^{\circ}\right]$ : Au(1)-C(1) 2.060(9), Au1-C1B 1.951(9), $A u(1)-P(1) \quad 2.2733(12), \quad A u(1)-A u(1) \# 1$ 3.2907(4), $C(1)-C(2)$ 1.205(2), $C(2)-C(3)$ 1.439(2), $C(1)-A u(1)-P(1) 168.0(7), C(1)-C(2)-C(3)$ $177.6(18)$. In complex 7 the oxygen atom is disordered, only distances to the main component are included.

results in the molecules being associated in chains with an intermolecular $\mathrm{Au}-\mathrm{Au}$ distance of 3.2907(4) $\AA$ (Fig. 5).

Reaction of complex 2 with one equivalent of $\left[\mathrm{Cu}\left(\mathrm{NO}_{3}\right)\right.$ $\left.\left(\mathrm{PPh}_{3}\right)_{2}\right]$ in dichloromethane gave the dimeric complex 9 (Scheme 2). The copper successfully binds to the alkyne bond of the propargyl unit and the triphenylphosphine ligands at the copper centre are displaced by the nitrogen donor pyridine and amine groups. The analogous reaction with $[\mathrm{Ag}(\mathrm{OTf})$ $\left.\left(\mathrm{PPh}_{3}\right)\right]$ led to a mixture of products due to the stronger affinity of the silver centre for phosphine over nitrogen ligands.

Complex 9 was characterised by single crystal X-ray diffraction. The molecule lies in a symmetry centre and only half of the molecule corresponds to the asymmetric unit (Fig. 6). Coordination of the copper to the alkyne triple bond results in a lengthening of the bond to 1.233(4) ^ compared to 1.173(7) $\AA$ for complex 2. The copper coordinates to the centre of the alkyne triple bond with distances $\mathrm{Cu}(1)-\mathrm{C}(1) 2.019(2) \AA$ and $\mathrm{Cu}(1)-\mathrm{C}(2)$ 2.004(2) $\AA$. In addition, the $\mathrm{Au}(1)-\mathrm{C}(1)$ bond is $1.999(3) \AA$, which is very similar to that in the starting complex 2 suggesting that coordination of the copper fragment does not significantly affect the strength of the gold-carbon bond. There are two short $\mathrm{Cu}-\mathrm{N}$ bonds, with lengths $\mathrm{Cu}(1)-\mathrm{N}(1)$ 2.033(2) $\AA$ and $\mathrm{Cu}(1)-\mathrm{N}(3)$ 2.017(2) $\AA$ to the nitrogens of the 


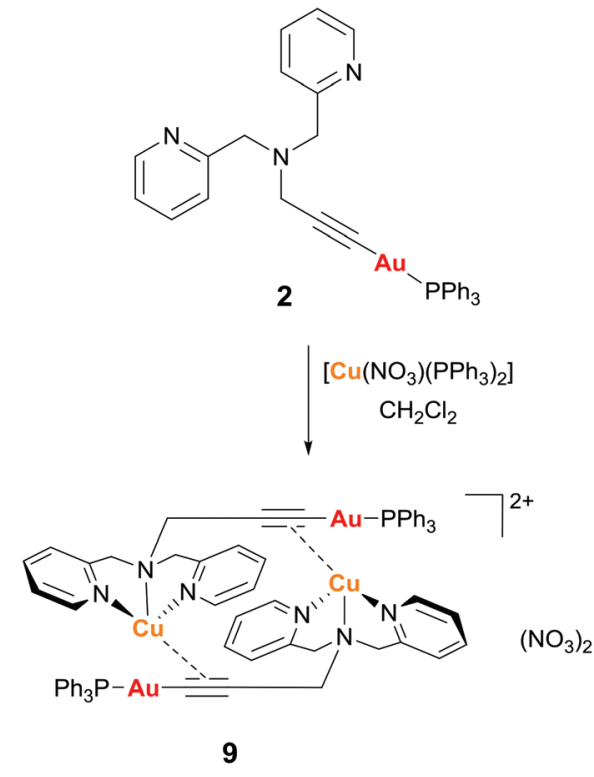

Scheme 2 Synthesis of complex 9.

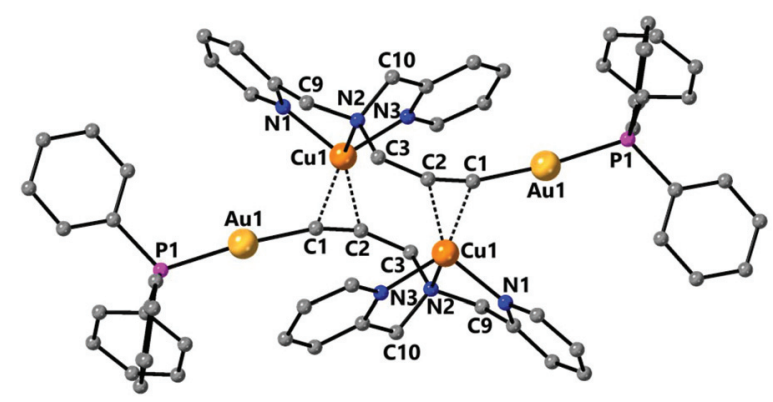

Fig. 6 Molecular structure of complex 9 determined by single crystal $\mathrm{X}$-ray diffraction. Selected bond lengths [Å] and angles [ $\left.{ }^{\circ}\right]$ : $\mathrm{Au}(1)-\mathrm{C}(1)$ 1.999(3), $\mathrm{Au}(1)-P(1)$ 2.2694(6), $\mathrm{Cu}(1)-\mathrm{C}(2)$ 2.004(2), $\mathrm{Cu}(1)-\mathrm{N}(3)$ 2.017(2), $\mathrm{Cu}(1)-\mathrm{C}(1)$ 2.019(2), $\mathrm{Cu}(1)-\mathrm{N}(1)$ 2.033(2), $\mathrm{Cu}(1)-\mathrm{N}(2) 2.264(2), \mathrm{C}(1)-\mathrm{C}(2)$ 1.233(4), C(2)-C(3) 1.479(3), C(1)-Au(1)-P(1) 171.15(7), C(2)-Cu(1)-N(3) 106.54(9), C(2)-Cu(1)-C(1) 35.70(10), N(3)-Cu(1)-C(1) 142.18(9), C(2)$\mathrm{Cu}(1)-\mathrm{N}(1) \quad 142.73(9), \quad \mathrm{N}(3)-\mathrm{Cu}(1)-\mathrm{N}(1) \quad 109.17(8), \quad \mathrm{C}(1)-\mathrm{Cu}(1)-\mathrm{N}(1)$ 108.27(9), C(2)-Cu(1)-N(2) 116.78(9), N(3)-Cu(1)-N(2) 80.69(8), C(1)$\mathrm{Cu}(1)-\mathrm{N}(2) 111.27(9), \mathrm{N}(1)-\mathrm{Cu}(1)-\mathrm{N}(2) 79.63(8), \mathrm{C}(1)-\mathrm{C}(2)-\mathrm{C}(3) 160.1(3)$.

pyridyl groups, and one longer $\mathrm{Cu}(1)-\mathrm{N}(2) 2.264(2) \AA$ to the amine nitrogen. The coordination about the gold centre is slightly distorted from linearity due to steric hindrance between the bulky triphenylphosphine ligand and the pyridyl groups with an angle $\mathrm{P}(1)-\mathrm{Au}(1)-\mathrm{C}(1) 171.15(7)^{\circ}$. The propargyl angle is considerably distorted from linearity as a result of the coordination of the copper, with an angle $\mathrm{C}(1)-\mathrm{C}(2)-\mathrm{C}(3)$ $160.1(3)^{\circ}$. The $\mathrm{Cu}(1)-\mathrm{Au}(1)$ distance of $3.535 \AA$ is too long to indicate the presence of any metallophilic interaction between the two metal centres.

The ${ }^{31} \mathrm{P}$ NMR spectrum of $\mathbf{9}$ displays a broad signal at room temperature, indicative of a fluxional process, however at $193 \mathrm{~K}$ this signal becomes a sharp singlet and the protons of the

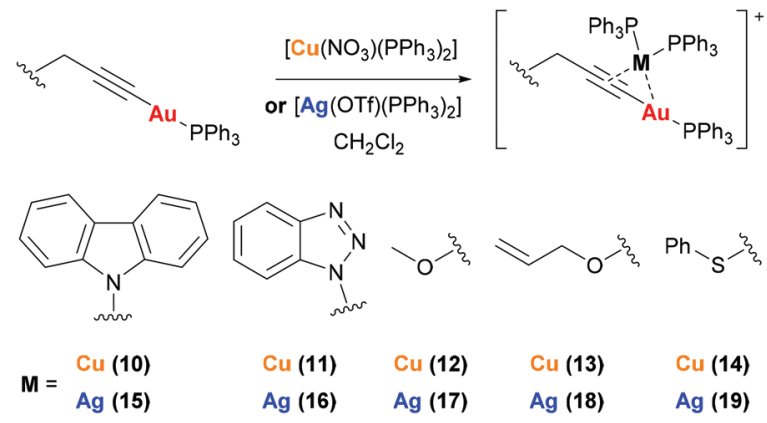

Scheme 3 Synthesis of heterometallic complexes 10-19.

$\mathrm{CH}_{2} \mathrm{Py}$ groups become inequivalent, in agreement with the solid-state structure.

Complexes 10-19 were prepared by reaction of mononuclear gold complexes 3-6 and 8 with $\left[\mathrm{Cu}\left(\mathrm{NO}_{3}\right)\left(\mathrm{PPh}_{3}\right)_{2}\right]$ or $[\mathrm{Ag}(\mathrm{OTf})$ $\left.\left(\mathrm{PPh}_{3}\right)_{2}\right]$ (Scheme 3). In these complexes the copper or silver binds to the alkyne triple bond, maintaining the two triphenylphosphine ligands. The identity of 10-19 can be confirmed by NMR studies. The ${ }^{1} \mathrm{H}$ NMR spectra show additional aromatic protons for the triphenylphosphine ligands and two broad peaks are observed in the ${ }^{31} \mathrm{P}\left\{{ }^{1} \mathrm{H}\right\}$ NMR spectra.

\section{Biological activity}

Complexes 2-19 were not soluble in water but were soluble in DMSO and mixtures of DMSO/water used to carry out the tests. Stability studies have been done for the mononuclear complexes in DMSO by ${ }^{1} \mathrm{H}$ NMR (Fig. S1-S9†) and the bimetallic complexes were tested in DMSO/PBS by UV-vis spectroscopy (Fig. S10-S16†) for a period of $24 \mathrm{~h}$. No changes were observed between the initial ${ }^{1} \mathrm{H}$ NMR or UV-vis spectra and the corresponding ones after $24 \mathrm{~h}$, confirming the retention of the complexes in solution. The biological activity of the complexes was studied by MTT assay for lung carcinoma cell line A549. The calculated $\mathrm{IC}_{50}$ values for the complexes after $24 \mathrm{~h}$ incubation are shown in Table 1.

The carbazole derivative, complex 3 , was the only complex not to show any antiproliferative activity against A549 cells at the concentrations tested with $\mathrm{IC}_{50}$ value of $>100 \mu \mathrm{M}$. The other monometallic gold complexes (2, 4-6 and 8) showed excellent $\mathrm{IC}_{50}$ values for $24 \mathrm{~h}$ incubation with the cancer cells. No significant differences are observed upon changing the heteroatom of the propargyl substrate as all of the $\mathrm{IC}_{50}$ values are within a similar range 9-13 $\mu \mathrm{M}$, the sulfur derivative, 8 , having the lowest $\mathrm{IC}_{50}$ value of the gold triphenylphosphine complexes at $9.11 \pm 1.93 \mu \mathrm{M}$. Dinuclear gold triphenylphosphine complex 7 , derivative of dipropargylether did not show a greater activity than the mononuclear propargylether derivatives 5 and 6 . There therefore appears to be no correlation between the number of gold-triphenylphosphine units in the complex and the overall activity. A comparison with the cytotoxicity of the reference cisplatin complex in the same conditions, $114.2 \pm 9.1 \mu \mathrm{M},{ }^{21}$ although measured in water, revealed a much higher activity for the gold complexes. 
Table $1 \mathrm{IC}_{50}$ Values for complexes 2-19, $\left[\mathrm{Cu}\left(\mathrm{NO}_{3}\right)\left(\mathrm{PPh}_{3}\right)_{2}\right]$ and $\left[\mathrm{Ag}(\mathrm{OTf})\left(\mathrm{PPh}_{3}\right)_{2}\right]$ after $24 \mathrm{~h}$ incubation with A549 cells

\begin{tabular}{|c|c|c|c|c|c|}
\hline Au complex & $\mathrm{IC}_{50}(\mu \mathrm{M})$ & $\mathrm{Au}-\mathrm{Cu}$ complex & $\mathrm{IC}_{50}(\mu \mathrm{M})$ & $\mathrm{Au}-\mathrm{Ag}$ complex & $\mathrm{IC}_{50}(\mu \mathrm{M})$ \\
\hline 2 & $13.32 \pm 0.51$ & $9^{a}$ & $1.37 \pm 0.21$ & & \\
\hline 3 & $>100$ & 10 & $6.16 \pm 0.18$ & 15 & $4.92 \pm 0.04$ \\
\hline 4 & $11.91 \pm 1.54$ & 11 & $2.50 \pm 0.19$ & 16 & $1.19 \pm 0.03$ \\
\hline 5 & $10.27 \pm 0.76$ & 12 & $1.78 \pm 0.18$ & 17 & $1.44 \pm 0.13$ \\
\hline 6 & $10.61 \pm 0.93$ & 13 & $1.60 \pm 0.18$ & 18 & $1.08 \pm 0.12$ \\
\hline 7 & $12.28 \pm 2.66$ & & & & \\
\hline \multirow[t]{2}{*}{8} & $9.11 \pm 1.93$ & 14 & $1.64 \pm 0.10$ & 19 & $1.44 \pm 0.13$ \\
\hline & & {$\left[\mathrm{Cu}\left(\mathrm{NO}_{3}\right)\left(\mathrm{PPh}_{3}\right)_{2}\right]$} & $4.17 \pm 0.19$ & {$\left[\mathrm{Ag}(\mathrm{OTf})\left(\mathrm{PPh}_{3}\right)_{2}\right]$} & $2.54 \pm 0.26$ \\
\hline
\end{tabular}

${ }^{a}$ Value for the mononuclear complex.

The introduction of the $\pi$-bound copper(I) or silver(I) ion had a huge effect on the antiproliferative activity of the complexes. In all cases the $\mathrm{IC}_{50}$ values were considerably lower, most notable for the carbazole derivatives where the gold complex 3 showed no activity but the gold-copper and goldsilver heterobimetallic complexes $\mathbf{1 0}$ and $\mathbf{1 5}$ did have antiproliferative activity. In all cases the derivatives with silver had slightly lower $\mathrm{IC}_{50}$ values than their copper analogues. It is also worth noting that other than with the carbazole derivatives, the heterometallic complexes all had $\mathrm{IC}_{50}$ values lower than the control compounds $\left[\mathrm{Cu}(\mathrm{NO})_{3}\left(\mathrm{PPh}_{3}\right)_{2}\right]$ or $[\mathrm{Ag}(\mathrm{OTf})$ $\left(\mathrm{PPh}_{3}\right)_{2}$ ], therefore the combination of two metals, $\mathrm{Au}$ and $\mathrm{Cu} /$ $\mathrm{Ag}$, is more potent than either complex separately.

\section{Experimental section}

\section{Experimental details}

Mass spectra were recorded on a BRUKER ESQUIRE 3000 PLUS, with the electrospray (ESI) technique. ${ }^{1} \mathrm{H},{ }^{13} \mathrm{C}\left\{{ }^{1} \mathrm{H}\right\}$ and ${ }^{31} \mathrm{P}$ NMR, including 2D experiments, were recorded at room temperature on a BRUKER AVANCE 400 spectrometer $\left({ }^{1} \mathrm{H}\right.$, $\left.400 \mathrm{MHz},{ }^{13} \mathrm{C}, 100.6 \mathrm{MHz},{ }^{31} \mathrm{P}, 162 \mathrm{MHz}\right)$ or on a Bruker Avance II 300 spectrometer $\left({ }^{1} \mathrm{H} 300.0 \mathrm{MHz},{ }^{13} \mathrm{C} 75.5 \mathrm{MHz},{ }^{31} \mathrm{P}\right.$ 121.5 MHz, $\left.{ }^{19} \mathrm{~F} 282.3 \mathrm{MHz}\right)$, with chemical shifts $(\delta, \mathrm{ppm})$ reported relative to the solvent peaks of the deuterated solvent. Infrared spectra were recorded in the range $4000-250 \mathrm{~cm}^{-1}$ on a PerkinElmer Spectrum 100 FTIR spectrometer.

\section{Crystal structure determinations}

Crystals were mounted in inert oil on glass fibres and transferred to the cold gas stream of an Xcalibur Oxford Diffraction (2) or a Smart APEX CCD diffractometers $(3-5,7,8)$ equipped with a low-temperature attachment. Data were collected using monochromated MoKo radiation $(\lambda=0.71073 \AA$ Å). Scan type $\varpi$. Absorption corrections based on multiple scans were applied using SADABS ${ }^{22}$ or spherical harmonics implemented in SCALE3 ABSPACK scaling algorithm. ${ }^{23}$ The structures were solved by direct methods and refined on $\mathrm{F}^{2}$ using the program SHELXT-2016, ${ }^{24}$ or and by using Olex 2 as the graphical interface. ${ }^{25}$ All non-hydrogen atoms were refined anisotropically. CCDC deposition numbers 2009440 (2), 2009441 (3), 2009442
(4), 2009443 (5), 2009444 (7), 2009445 (8) and 2009446 (9) contain the supplementary crystallographic data. $\dagger$

\section{Materials and procedures}

The starting materials $[\mathrm{AuCl}(\mathrm{tht})],{ }^{26}\left[\mathrm{AuCl}\left(\mathrm{PPh}_{3}\right)\right],{ }^{27}[\mathrm{Au}(\mathrm{acac})$ $\left.\left(\mathrm{PPh}_{3}\right)\right],{ }^{28}\left[\mathrm{Ag}(\mathrm{OTf})\left(\mathrm{PPh}_{3}\right)_{2}\right],{ }^{29}\left[\mathrm{Cu}\left(\mathrm{NO}_{3}\right)\left(\mathrm{PPh}_{3}\right)_{2}\right],{ }^{30} N$-propargyl-di (2-picolyl)amine ${ }^{31}$ and $N$-propargylcarbazole ${ }^{32}$ were prepared according to published procedures. All other reagents were commercially available and were used without further purification. Solvents were dried with a SPS solvent purification system.

\section{Cell culture}

A549 (human lung carcinoma) cells were maintained in high glucose DMEM (Dulbecco's Modified Eagle's Medium) supplemented with $5 \%$ fetal bovine serum (FBS), $200 \mu \mathrm{g} \mathrm{mL}^{-1}$ penicillin, $100 \mu \mathrm{g} \mathrm{mL} \mathrm{m}^{-1}$ streptomycin and $2 \mathrm{mM}$ L-glutamine.

\section{Antiproliferative studies: MTT assay}

Exponentially growing cells (A549) were seeded at a density of approximately $10^{4}$ cells per well in 96 well flat-bottomed microplates and allowed to attach for $24 \mathrm{~h}$ prior to addition of compounds. Various concentrations of the compounds $\left(0.1-100 \mu \mathrm{M}\right.$ ) were added and incubated for $24 \mathrm{~h}$ at $37^{\circ} \mathrm{C}$ (total volume $200 \mu \mathrm{l}$ ). Stock solutions of the compounds were prepared as $10 \mathrm{mM}$ DMSO solutions and diluted using DMEM media. The final concentration of DMSO in each well was $\leq 0.25 \%$. After $24 \mathrm{~h}, 10 \mu \mathrm{l}$ of MTT $\left(5 \mathrm{mg} \mathrm{ml}^{-1}\right.$ in PBS) was added to each well and the plates incubated for an additional $2 \mathrm{~h}$ at $37^{\circ} \mathrm{C}$. The media/MTT mixture was eliminated and DMSO $(100 \mu \mathrm{l}$ per well) was added to dissolve the formazan precipitates. The optical density was measured at $550 \mathrm{~nm}$ using a 96-well multiscanner autoreader (ELISA). Absorbance values were normalised to (DMSO-containing) control wells and plotted as concentration of compound versus \% cell viability. $\mathrm{IC}_{50}$ values were calculated by nonlinear regression analysis. The reported $\mathrm{IC}_{50}$ values are the average of three independent experiments, each consisting of four replicates per concentration level (overall $n=12$ ).

\section{General synthesis of $\left[\mathrm{Au}\left(\mathrm{C} \equiv \mathrm{CCH}_{2} \mathrm{R}\right)\left(\mathrm{PPh}_{3}\right)\right]$ via $[\mathrm{Au}(\mathrm{acac})$ $\left.\left(\mathbf{P P h}_{3}\right)\right]$}

To a solution of the corresponding $\mathrm{HC} \equiv \mathrm{CCH}_{2} \mathrm{R}(0.1 \mathrm{mmol})$ in $\mathrm{CH}_{2} \mathrm{Cl}_{2}(5 \mathrm{ml})$ was added $\left[\mathrm{Au}(\mathrm{acac})\left(\mathrm{PPh}_{3}\right)\right](0.0559 \mathrm{~g}, 0.1 \mathrm{mmol})$ 
and the solution stirred for $2 \mathrm{~h}$. The solution was filtered through Celite, the filtrate concentrated under reduced pressure to approximately $1 \mathrm{ml}$ and $\mathrm{Et}_{2} \mathrm{O}$ added to precipitate a solid of the corresponding compound.

\section{General synthesis of $\left[\mathrm{Au}\left(\mathrm{C} \equiv \mathrm{CCH}_{2} \mathrm{R}\right)\left(\mathrm{PPh}_{3}\right)\right]$ via $\left[\mathrm{AuCl}\left(\mathrm{PPh}_{3}\right)\right]$ and $\mathrm{KOH}$}

To a solution of the corresponding $\mathrm{HC} \equiv \mathrm{CCH}_{2} \mathrm{R}(0.2 \mathrm{mmol})$ in $\mathrm{MeOH}(15 \mathrm{ml})$ was added $\left[\mathrm{AuCl}\left(\mathrm{PPh}_{3}\right)\right]$ (0.0989 g, $\left.0.2 \mathrm{mmol}\right)$ and $\mathrm{KOH}(0.0168 \mathrm{~g}, 0.3 \mathrm{mmol})$ and the mixture stirred for $12 \mathrm{~h}$. A white precipitate formed which was collected, washed with $\mathrm{Et}_{2} \mathrm{O}$ and vacuum dried to give the corresponding product.

\section{General synthesis of heterometallic complexes}

To a solution of the corresponding gold complex $(0.2 \mathrm{mmol})$ in dichloromethane $(5 \mathrm{ml})$ was added $\left[\mathrm{Cu}\left(\mathrm{NO}_{3}\right)\left(\mathrm{PPh}_{3}\right)_{2}\right](0.1300 \mathrm{~g}$, $0.2 \mathrm{mmol})$ or $\left[\mathrm{Ag}(\mathrm{OTf})\left(\mathrm{PPh}_{3}\right)_{2}\right](0.1563 \mathrm{~g}, 0.2 \mathrm{mmol})$ and the solution stirred for $1 \mathrm{~h}$. The solution was concentrated under reduced pressure to approximately $1 \mathrm{ml}$ and hexane $(10 \mathrm{ml})$ added to precipitate a solid of the corresponding compound.

\section{Conclusions}

We have prepared and characterised new propargyl gold triphenylphosphine complexes bearing different functional groups and tested the anticancer activity of these in A549 cells. The propargyl gold compounds could be prepared by two different methods: addition of $\left[\mathrm{Au}(\mathrm{acac})\left(\mathrm{PPh}_{3}\right)\right]$ to a solution of the substrate in dichloromethane, or reaction of the substrate with potassium hydroxide and $\left[\mathrm{AuCl}\left(\mathrm{PPh}_{3}\right)\right]$ in methanol, however the "acac" method generally resulted in higher yields. Several derivatives were structurally characterised by single crystal X-ray diffraction with intermolecular contacts observed.

Heterometallic dinuclear gold(I) complexes with copper(I) and silver(I) were also prepared in which the copper or silver is bound to the triple bond of the propargyl unit.

We have for the first time used the alkyne bond to incorporate an additional metal centre into the complex in order to directly compare the antiproliferative activity of gold-copper and gold-silver heterobimetallic complexes. The use of the propargyl gold complexes as a tether for the cytotoxic copper or silver centres gave improved activities compared to the copper or silver starting complexes or the mononuclear gold complexes, suggesting a possible synergy between the two metal centres within the cell.

\section{Conflicts of interest}

There are no conflicts to declare.

\section{Acknowledgements}

The authors also thank Ministerio de Investigación e Invovación (CTQ2016-75816-C2-1-P, PID2019-104379RB-C21 and RED2018-102471-T) and Gobierno de Aragón-Fondo Social Europeo (Research Group E07_20R) for financial support of our research.

\section{Notes and references}

1 B. Rosenberg, L. Vancamp, J. E. Trosko and V. H. Mansour, Nature, 1969, 222, 385-386.

2 N. Liu, X. Li, H. Huang, C. Zhao, S. Liao, C. Yang, S. Liu, W. Song, X. Lu, X. Lan, X. Chen, S. Yi, L. Xu, L. Jiang, C. Zhao, X. Dong, P. Zhou, S. Li, S. Wang, X. Shi, P. Q. Dou, X. Wang and J. Liu, Oncotarget, 2014, 5, 5453-5471.

3 C. Marzano, V. Gandin, A. Folda, G. Scutari, A. Bindoli and M. P. Rigobello, Free Radical Biol. Med., 2007, 42, 872-881.

4 K. Kahlos, Y. Soini, M. Säily, P. Koistinen, S. Kakko, P. Pääkkö, A. Holmgren and V. L. Kinnula, Int. J. Cancer, 2001, 95, 198-204.

5 R. A. Stockland, M. C. Kohler, I. A. Guzei, M. E. Kastner, J. A. Bawiec, D. C. Labaree and R. B. Hochberg, Organometallics, 2006, 25, 2475-2485.4.

6 C.-H. Chui, R. S.-M. Wong, R. Gambari, G. Y.-M. Cheng, M. C.-W. Yuen, K.-W. Chan, S.-W. Tong, F.-Y. Lau, P. B.-S. Lai, K.-H. Lam, C.-L. Ho, C.-W. Kan, K. S.-Y. Leung and W.-Y. Wong, Bioorg. Med. Chem., 2009, 17, 7872-7877.

7 E. Schuh, S. M. Valiahdi, M. A. Jakupec, B. K. Keppler, P. Chiba and F. Mohr, Dalton Trans., 2009, 10841-10845.

8 E. Vergara, E. Cerrada, A. Casini, O. Zava, M. Laguna and P. J. Dyson, Organometallics, 2010, 29, 2596-2603.

9 R. G. Balasingham, C. F. Williams, H. J. Mottram, M. P. Coogan and S. J. A. Pope, Organometallics, 2012, 31, 5835-5843.

10 A. Meyer, C. P. Bagowski, M. Kokoschka, M. Stefanopoulou, H. Alborzinia, S. Can, D. H. Vlecken, W. S. Sheldrick, S. Wölfl and I. Ott, Angew. Chem., Int. Ed., 2012, 51, 88958899.

11 R. Gavara, E. Aguiló, J. Schur, J. Llorca, I. Ott and L. Rodríguez, Inorg. Chim. Acta, 2016, 446, 189-197.

12 N. Mirzadeh, S. H. Privér, A. Abraham, R. Shukla, V. Bansal and S. K. Bhargava, Eur. J. Inorg. Chem., 2015, 2015, 42754279.

13 I. Mármol, P. Castellnou, R. Alvarez, M. C. Gimeno, M. J. Rodriguez-Yoldi and E. Cerrada, Eur. J. Med. Chem., 2019, 183, 111661.

14 E. Cerrada, V. Fernández-Moreira and M. C. Gimeno, Adv. Organomet. Chem., 2019, 71, 227-257.

15 J. Fernandez-Gallardo, B. T. Elie, M. Sanau and M. Contel, Chem. Commun., 2016, 52, 3155.

16 E. García-Moreno, S. Gascón, M. J. Rodriguez-Yoldi, E. Cerrada and M. Laguna, Organometallics, 2013, 32, 3710-3720.

17 E. Barreiro, J. S. Casas, M. D. Couce, A. Sánchez, J. Sordo and E. M. Vázquez-López, J. Inorg. Biochem., 2014, 131, 68-75.

18 N. Curado and M. Contel, Heterometallic Compounds as Anticancer Agents, in Metal-based Anticancer Agents, ed. A. Casini, A. Vessières and S. M. Meier-Menches, Royal Society of Chemistry, London, 2019, ch. 6. 
19 M. C. Blanco, J. Cámara, M. C. Gimeno, P. G. Jones, A. Laguna, J. M. López-de-Luzuriaga, M. E. Olmos and M. D. Villacampa, Organometallics, 2012, 31, 2597-2605.

20 M. Hailmann, B. Hupp, A. Himmelspach, F. Keppner, P. T. Hennig, R. Bertermann, A. Steffen and M. Finze, Chem. Commun., 2019, 55, 9351-9354.

21 M. Frik, J. Fernández-Gallardo, O. Gonzalo, V. MangasSanjuan, M. González-Alvarez, A. Serrano del Valle, C. Hu, I. González-Alvarez, M. Bermejo, I. Marzo and M. Contel, J. Med. Chem., 2015, 58, 5825-5841.

22 G. M. Sheldrick, $S A D A B S$, Program for adsorption correction, University of Göttingen, Göttingen, Germany, 1996.

23 CrysAlisPro, Agilent Technologies, Version 1.171.35.11. Multi-scans absorption correction with SCALE3 ABSPACK scaling algorithm.

24 G. Sheldrick, Acta Crystallogr., Sect. A: Found. Adv., 2015, 71, 3-8.
25 O. V. Dolomanov, L. J. Bourhis, R. J. Gildea, J. A. K. Howard and H. Puschmann, J. Appl. Crystallogr., 2009, 42, 339-341.

26 R. Uson, A. Laguna, M. Laguna, D. A. Briggs, H. H. Murray and J. P. Fackler, in Inorg. Synth, John Wiley \& Sons, Inc., 1989, pp. 85-91.

27 C. A. McAuliffe, R. V. Parish and P. D. Randall, J. Chem. Soc., Dalton Trans., 1979, 1730-1735.

28 D. Gibson, B. F. G. Johnson and J. Lewis, J. Chem. Soc. A, 1970, 367-369.

29 M. Bardají, O. Crespo, A. Laguna and A. K. Fisher, Inorg. Chim. Acta, 2000, 304, 7-16.

30 F. A. Cotton and D. M. L. Goodgame, J. Chem. Soc., 1960, 5267-5269.

31 S. Huang, R. J. Clark and L. Zhu, Org. Lett., 2007, 9, 49995002 .

32 A. Balci, M. Arslan, A. R. Nixha, C. Bilen, A. Ergun and N. Gençer, J. Enzyme Inhib. Med. Chem., 2015, 30, 377-382. 